\title{
Seagrass species composition and above-ground carbon stock mapping in Parang Island using Planetscope image
}

Indinna Shofia Astuty, Pramaditya Wicaksono

Indinna Shofia Astuty, Pramaditya Wicaksono, "Seagrass species composition and above-ground carbon stock mapping in Parang Island using Planetscope image," Proc. SPIE 11311, Sixth Geoinformation Science Symposium, 1131103 (21 November 2019); doi: 10.1117/12.2549137

EDIE Event: Sixth Geoinformation Science Symposium, 2019, Yogyakarta, Indonesia 


\title{
Seagrass Species Composition and Above-Ground Carbon Stock Mapping in Parang Island using PlanetScope Image
}

\author{
Indinna Shofia Astuty, Pramaditya Wicaksono* \\ Cartography and Remote Sensing, Department of Geographic Information Science, Faculty of \\ Geography, Yogyakarta, Indonesia 55281 \\ Email: indinna29@gmail.com, *prama.wicaksono@ugm.ac.id \\ "Corresponding author
}

\begin{abstract}
Seagrass beds with various species are widespread in Indonesia, where one of them is on Parang Island. The important role of seagrasses as a store of carbon stocks that prevent an increase in earth temperature makes the seagrass species composition and carbon stocks on Parang Island need to be inventoried and known for their existence. Seagrass data, especially on Parang Island, is not yet available, so an inventory and mapping are needed. PlanetScope image is one image that is expected to be able to map biophysical information on seagrass beds. The objectives of this study are (1) to map the composition of seagrass species and (2) to map the seagrass above-ground carbon stock (AGC) and estimate the total seagrass AGC stored on Parang Island, Karimunjawa Islands using PlanetScope. The composition of seagrass species was obtained through multispectral classification (maximum likelihood, random forest, support vector machine) and AGC seagrass through empirical modeling. The class composition of seagrass species obtained was Cymodocea rotundata $(\mathrm{Cr})$, Enhalus acoroides (Ea), Thalassia hemprichii (Th), and EaThCr, with the accuracy of 32.16\%. Seagrass AGC empirical modeling has an R2 0.086. The DII23 water column corrected band has the highest accuracy for seagrass AGC mapping, which is $66.90 \%$ with a Standard Error of Estimate (SE) value of $4.78 \mathrm{gC} / \mathrm{m}^{2}$. The total estimated AGC of seagrass found on Parang Island is $50.15 \mathrm{t} \mathrm{C}$.
\end{abstract}

Keywords: seagrass, species, carbon stock, PlanetScope, classification, empirical model

\section{INTRODUCTION}

Seagrass is a flowering plant that functions as a habitat for coastal and marine biota, nutrient recyclers, sediment traps, and blue carbon sinks [1][2]. The increase in the amount of carbon stock is in line with the reduction in the amount of carbon in the atmosphere, in this case affecting the issue of climate change and increasing temperatures on earth [2]. Seagrasses also have economic value in the fisheries and tourism sector of USD 28,916 per hectare per year in 2014 [3].

Seagrass beds in Indonesia have 12 different species with an area of 1,506.93 $\mathrm{km}^{2}$. This makes seagrass a high carbon storage potential, so that it can have a positive impact on the coastal and surrounding environment. Seagrass beds that have many positive roles for the coastal and marine environment need to be managed and protected. One step that can be taken is mapping the seagrass composition species and carbon stocks. Composition spesies mapping is the initial step that needs to be taken before mapping and estimating seagrass carbon stocks because the value of carbon stocks is very dependent on seagrass conditions morphologically and physiologically. Whereas each area of seagrass has different conditions, especially leaf size, density. The difference in carbon stocks stored in various organisms on earth is very relevant to the binding properties and biomass of these organisms.

Mapping seagrass species composition and carbon stocks can be done by insitu data measurement, as well as by remote sensing. Remote sensing is able to study almost all phenomena of the earth's surface including seagrass beds, which of course through different approaches [4]. Previous works have demonstrated the capability of remote sensing to map seagrass properties [5][6][7][8].

Most regions in Indonesia have water conditions that are considered suitable as seagrass habitat, such as tides, water clarity, substrate dominated by sand, and located in tropical climates. One of the areas that has high seagrass biodiversity is the Karimunjawa Islands. The average seagrass percent cover is $59.94 \%$ and among the islands in the Karimunjawa Islands which have high seagrass diversity is Parang Island, which is one of the inhabited islands [9].

Sixth Geoinformation Science Symposium, edited by Sandy Budi Wibowo, Andi B. Rimba

Stuart Phinn, Ammar A. Aziz, Proc. of SPIE, Vol. 11311, 1131103 - @ 2019 SPIE

CCC code: $0277-786 \mathrm{X} / 19 / \$ 21 \cdot$ doi: $10.1117 / 12.2549137$ 
Seagrass habitat conditions narrow down the choice of optimal satellite imagery to be used for mapping the composition of seagrass species and estimating their carbon stocks. The development of high-resolution multispectral satellite sensors is demonstrated by the launch of PlanetScope satellite imagery by Planet Labs, which is capable of recording the entire surface of the earth with a resolution of $3 \mathrm{~m}$ and a temporal resolution of one day. At present, the capability of PlanetScope image has not been widely studied, especially in obtaining information on seagrass biodiversity. Previous research on seagrass mapping using PlanetScope's image was carried out by Wicaksono \& Lazuardi [8] related to mapping the composition of seagrass species. Therefore, it is necessary to study further the performance of PlanetScope image in obtaining other biophysical information on seagrass beds, namely carbon stock.

This study aims to map the composition of species and above-ground carbon stock (AGC) of seagrass beds on Parang Island, Karimunjawa Islands using PlanetScope image, and estimate the total seagrass AGC stored on Parang Island.

\section{METHODS}

\section{Overview}

This research was carried out in the optical shallow sea of Parang Island, as one of the areas with water conditions suitable for seagrass growth. However, information on the composition of species and carbon stocks of seagrass beds on this island is still not available. Parang Island is located on the west side of Karimunjawa Island and a trip to Parang Island can be reached in 2 hours from Karimunjawa Island by fast fishing boat. See Figure 1 for the location of Parang Island.

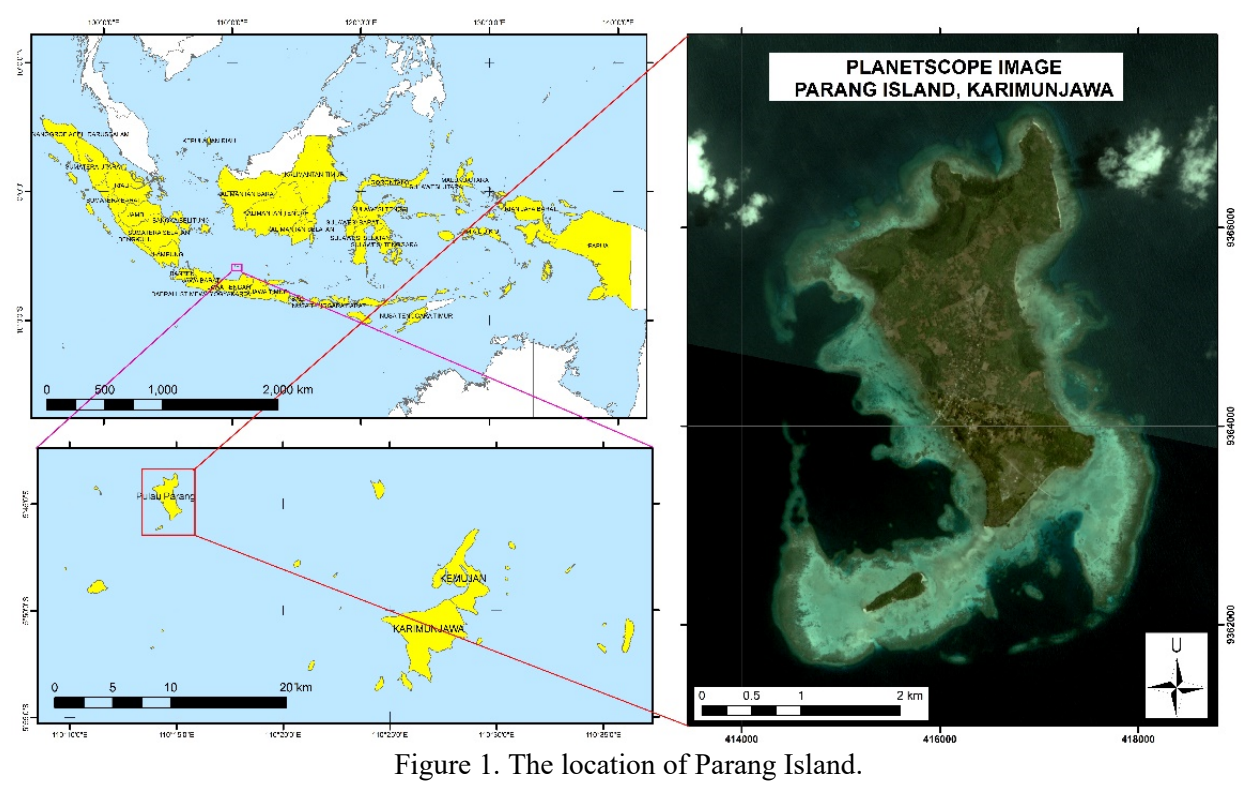

The image used is the image of PlanetScope with a spatial resolution of $3 \mathrm{~m}$ with the date of image acquisition on 11 April 2018. The condition of the image is quite clean without noise, clouds, and turbidity in the optically shallow water. Sunglint can be seen in optically deep water areas. The PlanetScope image used has been atmospherically corrected (surface reflectance product - SR), so the correction that needs to be done next was water column correction. Sunglint correction was not performed because sunglint does not visible in the optically shallow water.

Water column correction was required to reduce misidentification of underwater objects due to differences in water depth and the effect of water columns attenuation on reflection, scattering and absorption of electromagnetic waves [10]. The water column correction method developed by Lyzenga [11] was used in this study because it is considered still effective for clear waters with several considerations, such as the ease of image processing, simplicity of the algorithm, and does not require field measurements [10]. 


\section{Field survey}

Field data collection on the percentage of seagrass cover and composition of seagrass species were carried out using the photo-transect survey [12]. The surveyor photographed seagrass cover in parallel with the sea-floor, bringing GPS in tracking mode to record coordinates every 2 seconds, which has been adjusted to the clock on the camera. Photos are taken at $3 \mathrm{~m}$ intervals. The total number of photo-transect samples obtained was 1,166 sample points, which were divided into 4 classes of benthic habitats, namely macroalgae (102 samples), coral reef (424 samples), seagrass (290 samples), and bare substratum/sand (350 samples). The photo-quadrat survey was done by using quadrat made of $1 \times 1 \mathrm{~m}$ peralon, which is placed on top of seagrass. In addition, to obtain information on seagrass AGC, harvest sampling was carried out for each species found.

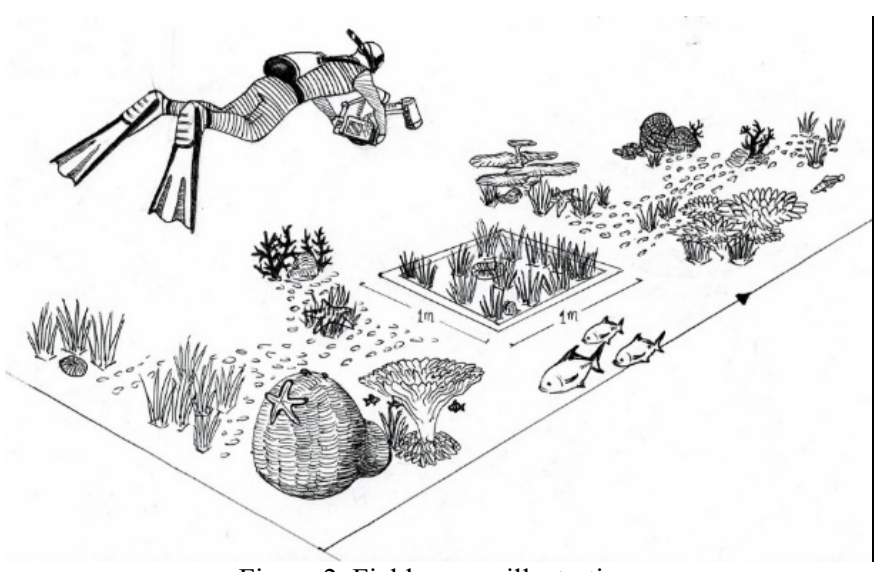

Figure 2. Field survey illustration.

\section{Field data analysis}

Samples from several seagrass species harvested in the field were used as laboratory test samples. Carbon stock laboratory testing only used the leaf parts, so that the AGC value can be obtained for each seagrass species. The time of each photo of the survey results was matched with the time on the GPS so that each photo has certain coordinates for identification of benthic habitat, seagrass species and the percentage of seagrass cover. To build empirical equations between image pixel values and seagrass AGC, information on spatial distribution of seagrass species composition is needed so that the composition mapping of seagrass species was carried out first.

Before conducting seagrass species composition classification, the classification of benthic habitat with four classes, i.e, coral reef, seagrass, macroalgae, and bare substratum was carried out. The water column corrected image was used as an input for the classification of benthic habitat. The multispectral classification of benthic habitat was carried out using three algorithms, namely maximum likelihood, random forest (RF), and support vector machine (SVM). The classification results from these different supervised algorithms were compared, in order to determine the best seagrass species composition map, which was used as the basis for AGC seagrass mapping. The classification results of benthic habitat and composition of seagrass species are calculated for accuracy using confusion matrix. Confusion matrix compares the classification data with reference data in the same coverage area [13].

Carbon stock estimation modeling was conducted by building an empirical model between field seagrass AGC data and pixel values of water column corrected image. The selection of significant variables was carried out using Pearson Correlation Product Moment analysis. Bands that have a significant relationship with AGC seagrass were used as input in the regression analysis, where the independent variable is the pixel value of each band in the water column corrected image. Based on the obtained empirical model, accuracy tests were carried out using the Standard Error of Estimate (SE) method using independent samples obtained through field surveys [14].

$$
S E=\sqrt{\frac{\sum\left(\left(y^{\prime}-y\right)^{2}\right.}{(n-2)}}
$$

where:

- $\quad y^{\prime}:$ predicted seagrass AGC 
- y: seagrass AGC reference

- $\mathrm{n}$ : number of samples

\section{RESULTS AND DISCUSSION}

\section{Seagrass AGC laboratory measurement}

Drying of leaf samples to calculate AGC values is carried out for almost 48 hours at high temperatures, because seagrasses are objects that have a high water content. The results obtained from laboratory tests are the AGC value of each seagrass species, which is then used to calculate the amount of seagrass carbon in each sample differentiated by species. These species are Enhalus acoroides (Ea), Thalassia hemprichii (Th), Cymodoicea rotundata (Cr), Syringodium isoetifolium (Si), Cymodocea serrulata (Cs), and Halophila ovalis (Ho).

Table 1. Laboratory test of seagrass AGC for each species per leaf.

\begin{tabular}{cc}
\hline Species code & gram C per leaf $(\mathbf{g})$ \\
\hline $\mathrm{Ea}$ & 0,311 \\
$\mathrm{Cr}$ & 0,027 \\
$\mathrm{Ho}$ & 0,010 \\
$\mathrm{Cs}$ & 0,041 \\
$\mathrm{Si}$ & 0,019 \\
$\mathrm{Th}$ & 0,023 \\
\hline
\end{tabular}

The results of seagrass carbon stock laboratory tests show that the organic carbon content in each leaf of Ea has the highest value compared to the organic carbon content of other species, while the one with the lowest value is Ho. This can occur because of differences in the average size of leaves of each species. Enhalus acoroides species have a larger and longer leaf size than other species, while Ho species are much smaller and rounded in shape.

Seagrass leaf carbon stock data and the number of seagrass leaves that have been calculated per samples are the input to calculate seagrass AGC of each sample. Seagrass AGC for each sample as used to build an empirical model of carbon stock mapping and calculate the accuracy of the estimation model.

\section{Benthic habitat classification}

The spatial distribution of seagrass beds in the maximum likelihood classification results appear clustered and tend to be distributed near to the coastline. Whereas in RF and SVM, seagrass beds appear more scattered and not clustered, and are located between the sand substrate. In general, seagrass Parang Island were classified spread around the entire island and were quite dominant compared to other benthic habitats. See Figure 2 for the comparison of benthic habitat classification results.
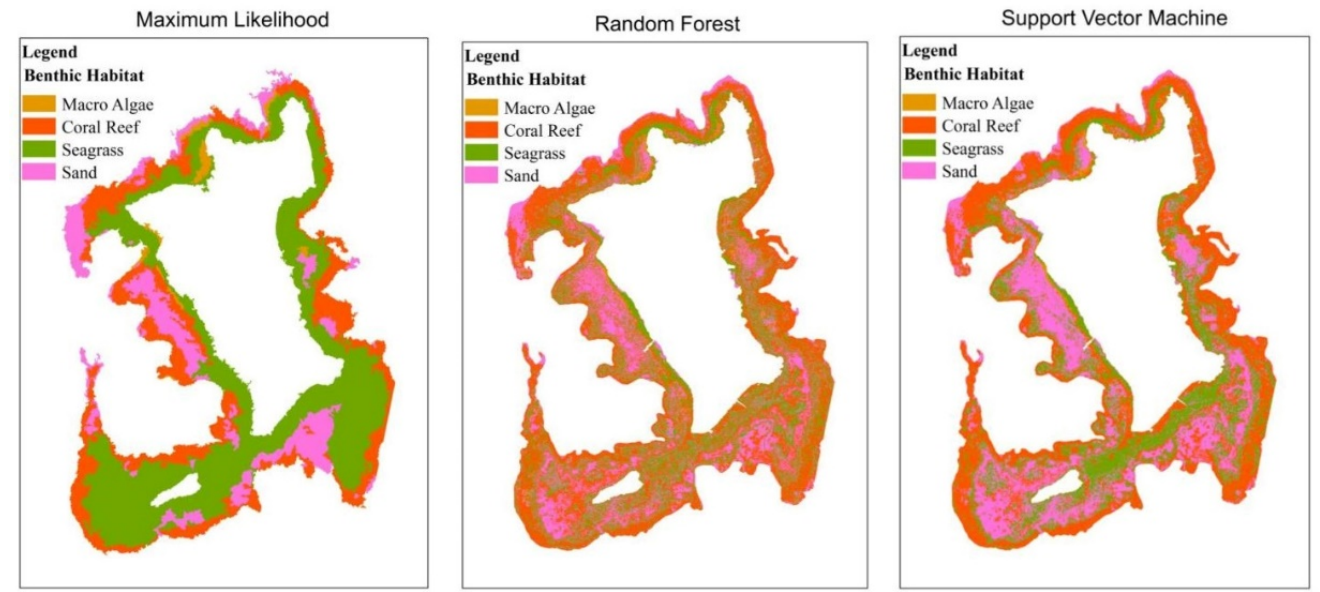

Figure 3. Comparison of benthic habitat classification result from maximum likelihood, RF, and SVM algorithms. 
The classification of benthic habitat from RF and SVM has a higher overall accuracy (OA), but the highest user's accuracy (UA) and producer's accuracy (PA) of seagrass classes were obtained from the maximum likelihood (Table 2).

\begin{tabular}{|c|c|c|c|}
\hline $\begin{array}{c}\text { Classification } \\
\text { algorithm }\end{array}$ & OA (\%) & UA (\%) & PA (\%) \\
\hline $\begin{array}{l}\text { Maximum } \\
\text { likelihood }\end{array}$ & 40.41 & 70.35 & 42.90 \\
\hline Random forest & 45.29 & 37.90 & 32.19 \\
\hline $\begin{array}{l}\text { Support vector } \\
\text { machine }\end{array}$ & 51.57 & 38.46 & 35.96 \\
\hline
\end{tabular}

Because this study focused on seagrass, the UA and PA of seagrass class were used as the main consideration in determining the best spatial distribution of seagrass in Parang Island. Considering the UA and the seagrass PA are high, the possibility of seagrass is correctly classified is also higher. Based on these results, the results of the classification of maximum likelihood with high UA and PA for seagrass class was used to mask seagrass areas in the classification of seagrass species composition. The spatial distribution of seagrass class based on maximum likelihood result is shown in Figure 4.

Figure 4 shows that the distribution of benthic habitats on Parang Island has a particular pattern in each class. The map shows that seagrasses dominate around the island. Coral reefs are mostly bordered directly with the optically deep water and some others are between the sand substrate, as well as the results of the RF and SVM classification. Sand class was also found near the optically shallow water. Coral reef in Parang Island tend to be widely found in the western and eastern regions. Sand object in the results the third classification of algorithms is in the southern and eastern regions. Macro algae only slightly mapped on Parang Island with all three classification methods in the east and north parts. The last object is the seagrass beds, which scattered around the island with quite dominating coverage compared to other benthic habitats. Maximum likelihood algorithm indicates seagrass beds, which are clustered and tend grow near the shoreline.

With a total area of optically shallow water of $8.33 \mathrm{~km}^{2}$, seagrass cover dominates up to $45.36 \%$ with $3.78 \mathrm{~km}^{2}$. Coral reef area is $2.24 \mathrm{~km}^{2}(26.9 \%)$, sand substrate is $1.78 \mathrm{~km}^{2}(21.43 \%)$, and macro algae $0.52 \mathrm{~km}^{2}(6.27 \%)$.

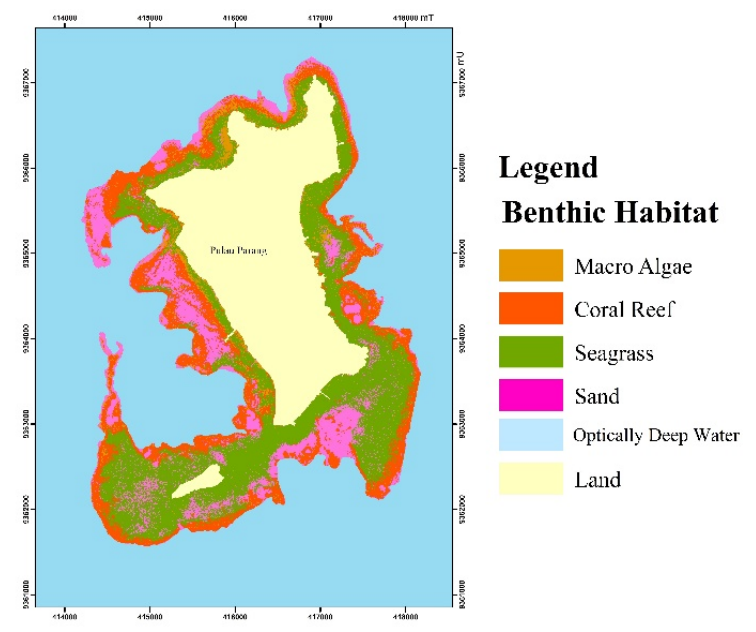

Figure 4. Maximum likelihood classification result of benthic habitat in Parang Island.

\section{Seagrass species composition mapping}

The distribution of seagrass on Parang Island tends not to form seagrass beds with single species when viewed visually during field surveys. Therefore, the determination of species class cannot be carried out only per one particular 
species, but rather a combination of several species into the composition of species (Table 3). The construction of seagrass species composition classification scheme was carried out by considering the interactions of electromagnetic energy, biophysical conditions of seagrasses, and dominating seagrass species [14].

Table 3. Classification scheme of seagrass species composition used for mapping.

\begin{tabular}{lll}
\hline No. & $\begin{array}{c}\text { Species } \\
\text { composition } \\
\text { class }\end{array}$ & \\
\hline 1 & $\mathrm{Cr}$ & Area dominated by $\mathrm{Cr}$ \\
\hline 2 & $\mathrm{EaThCr}$ & Mixed area of $\mathrm{Ea}, \mathrm{Th}$, and $\mathrm{Cr}$ with relatively proportional composition \\
\hline 3 & $\mathrm{ThCr}$ & $\begin{array}{l}\text { Mixed area between } \mathrm{Th} \text { and } \mathrm{Cr} \text { with relatively proportional composition. } \mathrm{Cs}, \mathrm{Si}, \text { and Ho can also be } \\
\text { found with minor percentage. }\end{array}$ \\
\hline 4 & $\mathrm{Th}$ & Area dominated by $\mathrm{Th}$ \\
\hline 5 & $\mathrm{Ea}$ & Area dominated by $\mathrm{Ea}$ \\
\hline
\end{tabular}

The samples that have been labeled based on the classification scheme in Table 3 were separated into training area and accuracy assessment samples. The number of training area for seagrass species composition mapping in $\mathrm{Cr}$ class is 134, Ea class is 6, EaThCr class is 20, Th class is 81 , and ThCr class is 60 , and therefore, the total number of training areas is 301 samples. These sample were used to train the maximum likelihood algorithm. The result can be seen in Figure 4.

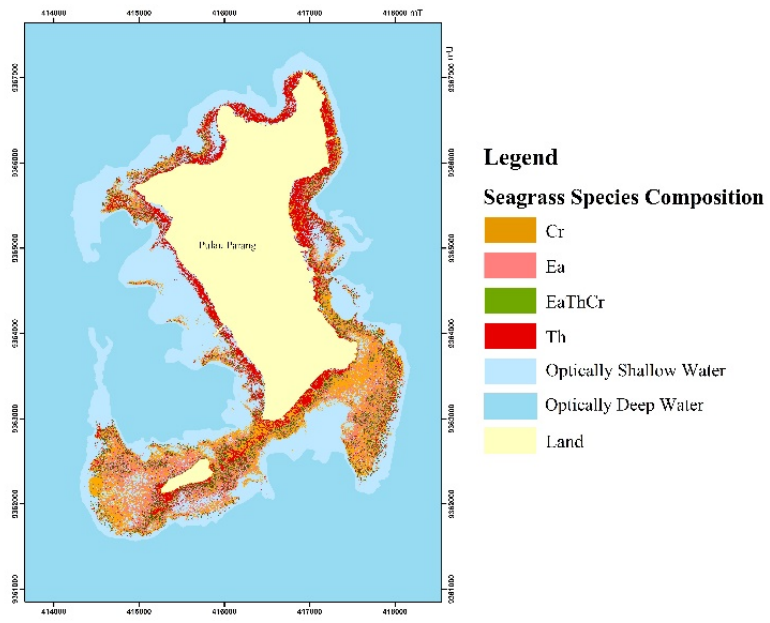

Figure 5. Seagrass species composition map obtained from maximum likelihood classification algorithm.

One class, namely ThCr, was not classified on the maximum likelihood classification result. This might happen because the spectral response of the ThCr class are very similar to other classes, so that they were classified into the same class, or PlanetScope's image capabilities are limited in distinguishing those classes. The total area of seagrass mapped is $3,778,551 \mathrm{~m}^{2}$ or $3.78 \mathrm{~km}^{2}$, with Cr class of $1.26 \mathrm{~km}^{2}$, Ea of $1.1 \mathrm{~km}^{2}$, EaThCr of $0.5 \mathrm{~km}^{2}$, and Th of 0.97 $\mathrm{km}^{2}$.

The seagrass species composition classification result in Parang Island was tested for accuracy with the accuracy assessment samples. The number of test samples used was 301 samples and the OA obtained was $32.16 \%$ (Table 4). This accuracy is much lower when compared to the [15] study, which obtained an OA of seagrass mapping of $70.37 \%$ using WorldView-2 image as well as from [8], with OA reaching $74.31 \%$ using PlanetScope imagery. The overall accuracy value this time is lower than [6], which has an overall accuracy of $77 \%$ using OBIA. This might happen because of the similarity of the reflection value of seagrass objects of each species so that it is difficult to distinguish from the classification of maximum likelihood and the difference in image resolution used. The unexplained $\mathrm{ThCr}$ is also a factor in decreasing the accuracy of species composition. 
Table 4. Confusion matrix of seagrass species composition classification using Maximum Likelihood. The highlighted columns indicate the number of reference data correctly classified.

\begin{tabular}{|c|c|c|c|c|c|c|c|}
\hline & \multicolumn{6}{|c|}{ Reference } & \multirow[b]{2}{*}{ Total } \\
\hline \multirow{6}{*}{ 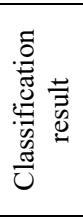 } & Class & $\mathrm{Cr}$ & $\mathrm{Ea}$ & EaThCr & Th & $\mathrm{ThCr}$ & \\
\hline & $\mathrm{Cr}$ & 28 & 2 & 5 & 11 & 4 & 50 \\
\hline & $\mathrm{Ea}$ & 26 & 1 & 3 & 14 & 17 & 61 \\
\hline & EaThCr & 14 & 1 & 3 & 1 & 3 & 22 \\
\hline & $\mathrm{Th}$ & 44 & 2 & 7 & 50 & 19 & 122 \\
\hline & $\mathrm{ThCr}$ & 0 & 0 & 0 & 0 & 0 & 0 \\
\hline & Total & 112 & 6 & 18 & 76 & 43 & 255 \\
\hline
\end{tabular}

\section{Seagrass AGC mapping}

The empirical model of AGC mapping of seagrass beds will initially be carried out per species, but with the OA of species mapping only $32.16 \%$ and the ThCr class was not classified, it makes the AGC models of seagrass will be difficult to obtain acceptable accuracy due to propagation errors from seagrass species composition mapping. The making of the seagrass AGC empirical model was then carried out at the community level without considering variations in species. Samples for the AGC empirical model were separated into sample models and sample accuracy assessment by considering the variations in seagrass percent cover [14].

The pixel values of each sample were extracted from each band of the water column corrected image, namely DII12 (blue-green), DII13 (blue-red), and DII23 (red-green). Furthermore, the pixel values of these DIIs were correlated with the seagrass AGC data to determine the independent variables that can be used as regression inputs.

Table 5. Correlation coefficient $(r)$ between field seagrass AGC and water column corrected bands.

\begin{tabular}{lccc}
\hline & DII23 & DII13 & DII12 \\
\hline $\begin{array}{l}\text { Field seagrass } \\
\text { AGC }\end{array}$ & -0.296 & -0.278 & -0.227 \\
\hline
\end{tabular}

Although the correlation was low, the three DII bands had a significant relationship with seagrass AGC $(\alpha=$ $0.05, n=254$ ). The correlation coefficients of the three channels are similar, and DII23 has the highest correlation coefficient with seagrass AGC field data. The resulting correlation properties are negative, where increasing AGC seagrass values will produce low spectral response of seagrass. This is because there is an increase in energy absorption by seagrass with high biomass. Some issues that may affect the weak correlation between seagrass AGC and image pixel values include the high noise level of the PlanetScope image as discussed in [8], errors in the calculation of leaf number through photos where ideally the leaves are calculated directly in the field, and displacement of GPS coordinates reading in the field, which causes the location of the field sample and its correspondeing pixel to be incorrect. Finally, these three bands were used to construct a linear regression equation for seagrass AGC estimation modeling on Parang Island.

The coefficient of determination $\left(R^{2}\right)$ of the three DII bands is between $0.05-0.09$, as shown in Figure 5 and Table 6. This shows that only less than $10 \%$ of seagrass AGC variations can be explained by PlanetScope DII bands. However, a low $R^{2}$ value does not necessarily ensure that the model produces low accuracy.

Table 6. Summary of empirical model for modeling seagrass AGC using PlanetScope DII bands.

\begin{tabular}{ccc}
\hline Band & $\boldsymbol{R}^{\mathbf{2}}$ & \multicolumn{1}{c}{ Regression function } \\
\hline DII23 & 0.086 & AGC $=-11.131 \mathrm{DII} 23+45.39$ \\
DII13 & 0.077 & AGC $=-8.571 \mathrm{DII} 13+42.78$ \\
DII12 & 0.051 & AGC $=-21.632 \mathrm{DII} 12+34.48$ \\
\hline
\end{tabular}



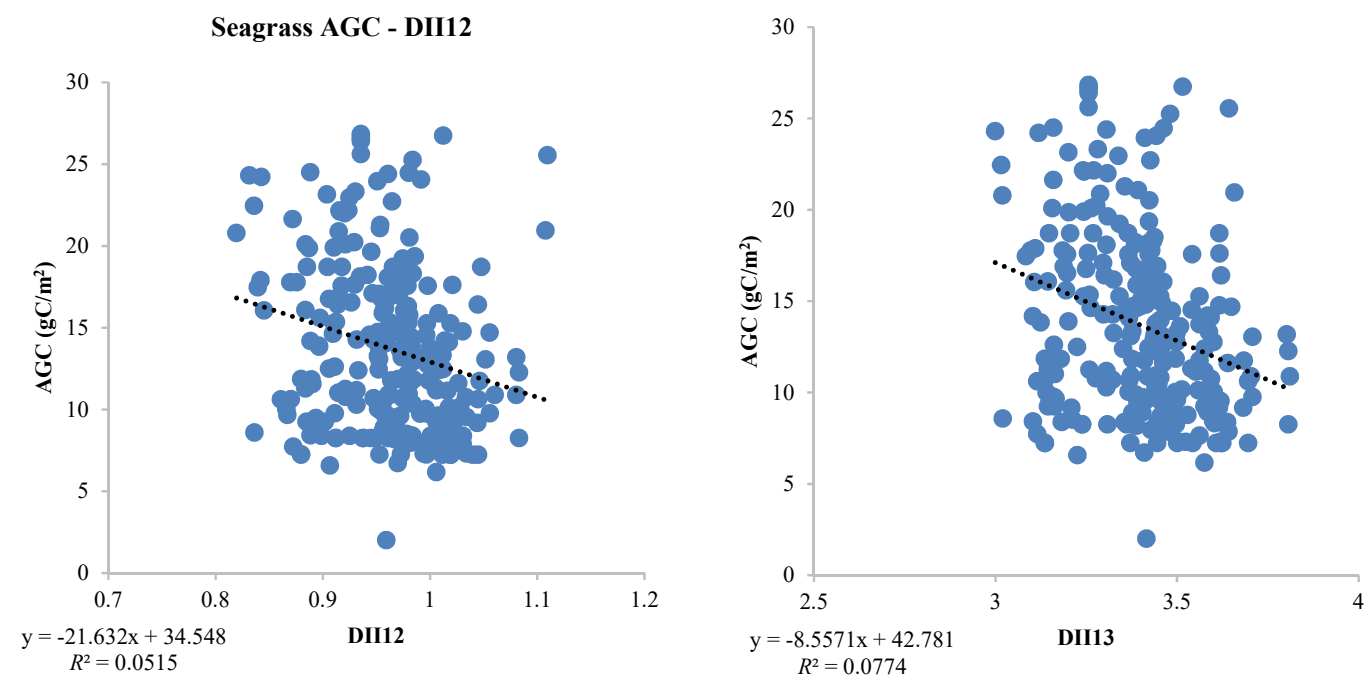

Seagrass AGC - DII23

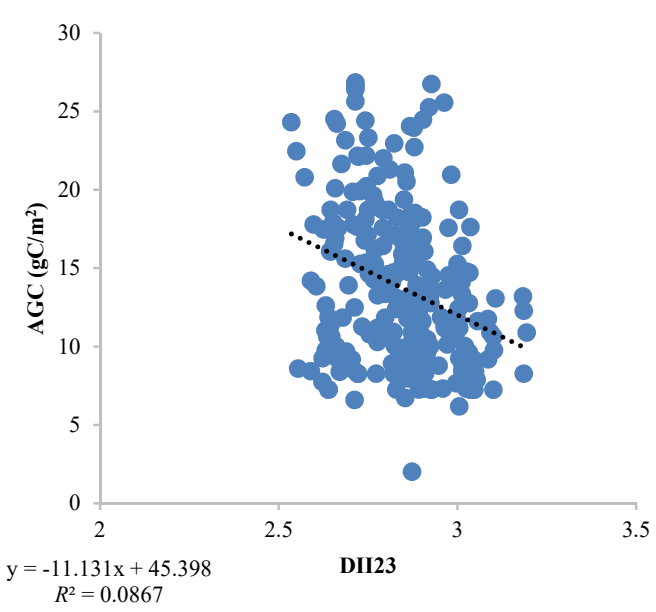

Figure 6. Scatterplot between field seagrass AGC and DII bands.

Seagrass AGC modeling results from the empirical model were calculated for SE and accuracy. The number of accuracy assessment samples for calculating SE is 248. The SE of the DII23, DII13, and DII13 models has a low difference, so the accuracy is not much different. The lowest SE value was produced by DII23, while the highest SE value was produced by DII12. The lower the SE value, the higher the accuracy. The SE of this seagrass AGC model is lower than the [16] study with SE values reaching $10.38 \mathrm{gC} / \mathrm{m}^{2}$ and $13.18 \mathrm{gC} / \mathrm{m}^{2}$. The value of SE and accuracy shows that the band that is best used to make AGC seagrass maps in this study is DII23 with SE $4.78 \mathrm{gC} / \mathrm{m}^{2}$ and accuracy of $66.90 \%$ (Figure 6). Based on the modeling using DII23, the seagrass AGC on the optically shallow water of Parang Island is estimated to be around $50.15 \mathrm{t} \mathrm{C}$.

The carbon stock modeling with WorldView-2 conducted by [15] resulted in an accuracy of each species ranging from $53.22 \%$ and $92.91 \%$, while [14] with various image to map carbon stocks with an accuracy of $49.23 \%$, and [16] using Quickbird Level 2A produces an accuracy of 40.91\%-48.31\%. This shows that the accuracy of the carbon stock model in this study is at a fair value. In addition, the ability of remote sensing to model carbon stocks on seagrass surfaces at high resolution and at moderate levels is still not much different. 
Table 7. Summary of SE and accuracy of seagrass AGC model.

\begin{tabular}{ccc}
\hline Band & SE $\left(\mathbf{g C} / \mathbf{m}^{\mathbf{2}}\right)$ & Accuracy $\mathbf{( \% )}$ \\
\hline DII23 & 4.78 & 66.90 \\
DII13 & 4.81 & 66.75 \\
DII12 & 4.89 & 66.20 \\
\hline
\end{tabular}

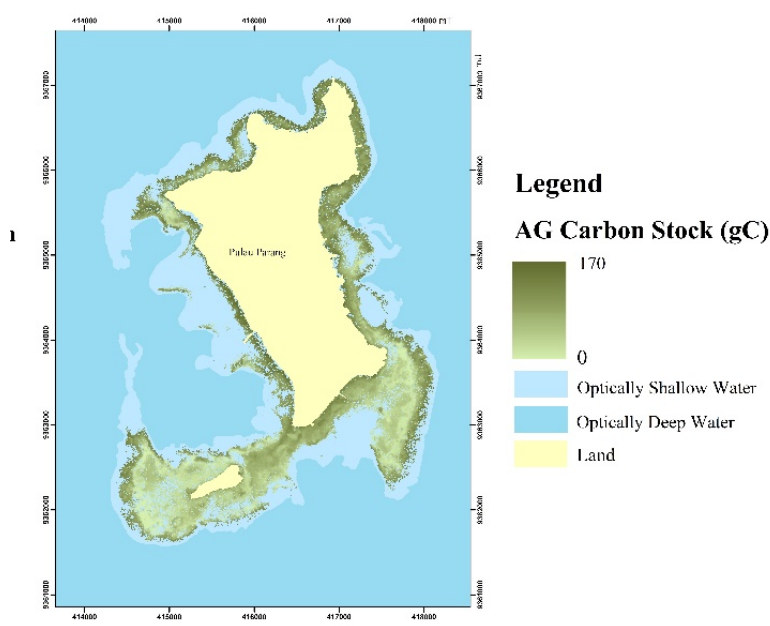

Figure 7. Map of seagrass AGC modeled from DII23 with SE $4.78 \mathrm{gC} / \mathrm{m}^{2}$ and $66.90 \%$ accuracy.

\section{CONCLUSIONS}

Seagrass species found on Parang Island, Karimunjawa Islands are Cr, Cs, Ea, Ho, Si, and Th. Based on the results of seagrass species composition mapping using maximum likelihood classification algorithm, seagrass was mapped into 4 classes namely $\mathrm{Cr}$, Ea, EaThCr, and Th with an OA of $32.16 \%$. Cr class was mapped at $1.22 \mathrm{~km}^{2}$ or $32.2 \%$ of the total area of seagrass beds in Parang Island, dominating the southern part of the island nearing the optically deep water. Ea class is $1.1 \mathrm{~km}^{2}(29.1 \%)$ and EaThCr class is $0.49 \mathrm{~km}^{2}(13.1 \%)$, both spread across the east to southwest of the island. Th class covers an area of $0.97 \mathrm{~km}^{2}(25.6 \%)$ around Parang Island near the coastline. ThCr was not classified by maximum likelihood algorithm because the spectral response is very similar to other classes. The total area of seagrass beds is $3.78 \mathrm{~km}^{2}$.

The high seagrass AGC dominates in the north and east of Parang Island, Karimunjawa Islands near the coastline. The lower seagrass AGC dominates in the southeast to the west of the island. The best AGC empirical model was obtained from PlanetScope DII23 with SE of $4.78 \mathrm{gC} / \mathrm{m}^{2}$ and accuracy of $66.90 \%$. The total estimation of seagrass AGC on Parang Island, Karimunjawa Islands is $50.15 \mathrm{t} \mathrm{C}$. This value tends to be low for seagrass areas of $3.78 \mathrm{~km}^{2}$.

\section{REFERENCES}

[1] COREMAP-CTI LIPI, [Status Padang Lamun Indonesia], Puslit Oseanografi-LIPI, Jakarta, 6-7 (2017).

[2] Nellemann, C., Corcoran, E., Duarte, C., Valdes, L., DeYoung, C., Fonseca, L., \& Grimsditch, G. "Blue Carbon: A Rapid Response Assessment", Birkeland Trykkeri AS, Norway (2009).

[3] Wahyudin, Y., Kusumastanto, T., Adrianto, L., \& W., Y., "Jasa Ekosistem Lamun Bagi Kesejahteraan Manusia", Omni-Akuatika, 29-46 (2016).

[4] Yang, X., "Remote Sensing and Geospatial Technologies for Coastal Ecosystem Assessment and Management", Lecture Notes in Geoinformation and Cartography, Berlin (2009).

[5] Phinn, S., Roelfsema, C., Dekker, A., Brando, V., \& Anstee, J., "Mapping seagrass species, cover and biomass in shallow waters: An assessment of satellite multi-spectral and airborne hyper-spectral imaging systems in Moreton Bay (Australia)", Remote Sensing of Environtment 112, 3413-3425 (2008).

[6] Roelfsema, C. M., Lyons, M., Kovacs, E., Maxwell, P., Saunders, M., Samper-Villareal, J., \& Phinn, S. (2014). Multi-temporal Mapping of Seagrass Cover, Species, and Biomass: A Semi-automated Object Based Image Analysis Approach. Remote Sensing of Environment 150, 172-187 (2014). 
[7] Fauzan, M. A., Kumara, I. S. W., Yogyantoro, R. N., Suwardhana, S. W., Fadhilah, N., Apriyani, S., Nurmalasari, I., Wicaksono, P., "Assessing the Capability of Sentinel-2 Data for Mapping Seagrass Percent Cover in Jerowaru, East Lombok.” Indonesian Journal of Geography 49 (2), 195 - 203 (2017)

[8] Wicaksono, P., and W. Lazuardi. "Assessment of PlanetScope images for benthic habitat and seagrass species mapping in a complex optically shallow water environment." International Journal of Remote Sensing, 39(17), 5739-5765 (2018).

[9] Azkab, M., “Ada Apa dengan Lamun”, Oseana Vol .XXXI, 44-55 (2006).

[10]Zoffoli, M. L., Frouin, R., \& Kampel, M. "Water Column Correction for Coral Reef Studies by Remote Sensing”, Sensors Vol. 14, 16881-16931 (2014).

[11] Lyzenga, D.R. "Passive Remote Sensing Techniques for Mapping Water Depth and Bottom Features", Applied Optics, 17, 379-383 (1978).

[12] Roelfsema, C. M. and S.R. Phinn, "Integrating field data with high spatial resolution multispectral satellite imagery for calibration and validation of coral feer benthic community maps", Journal of Applied Remote Sensing Vol. 4, 1-28 (2010).

[13] Congalton, R., \& Green, K., [Assessing the Accuracy of Remotely Sensed Data: Principles and Practices. 2nd Edition.], CRC Press, Boca Raton (2008).

[14] Wicaksono, P., "Remote Sensing Model Development for Seagrass and Mangroves Carbon Stock Mapping", Fakultas Geografi UGM, Yogyakarta (2015).

[15] Kalam, N. H. "Pemanfaatan Citra Multispektral WorldView-2 untuk Estimasi Stok Karbon Padang Lamun: Kajian di Perairan Pulau Pari, Taman Nasional Kepulauan Seribu DKI Jakarta.”, Fakultas Geografi UGM, Yogyakarta (2016).

[16] Hafizt, M. "Kajian Estimasi Standing Carbon Stock Padang Lamun Menggunakan Citra Quickbird di Pulau Kemujan Kepulauan Karimunjawa.”, Fakultas Geografi UGM, Yogyakarta (2013). 